Kamila Stańczak-Strumilto

Zaakceptowany: 12.05.2020

Uniwersytet Gdański

\title{
Instytucjonalne wykluczenie emerytalne w wąskim ujęciu jako rodzaj wykluczenia finansowego w Polsce
}

\section{INSTITUTIONAL PENSION EXCLUSION AS A NARROW APPROACH TO A TYPE OF FINANCIAL EXCLUSION IN POLAND}

\begin{abstract}
Problematyka wykluczenia finansowego stanowi istotny obszar badań we wspótczesnej nauce finansów głownie ze względu na poważne skutki jakie zjawisko to implikuje zarówno w makro (dla gospodarki, sektora finansowego), jak i mikro skali (dla konsumentów ustug finansowych). Obserwujac zmiany $w$ demografii (wydtużanie się życia, starzenie społeczeństw) oraz spadek prognozowanych stóp zastapienia w bazowych systemach emerytalnych szczególnego znaczenia nabiera kategoria wykluczenia emerytalnego, polegajaca na ograniczonym dostęie jednostek do produktów emerytalnych.

Celem artykulu jest określenie istoty i miary wykluczenia emerytalnego oraz próba kwantyfikacji tego zjawiska $w$ Polsce $w$ latach 2006-2017. O oryginalności opracowania stanowi autorska definicja instytucjonalnego wykluczenia emerytalnego $w$ szerokim $i$ waskim ujęciu, a także podjęta próba pomiaru instytucjonalnego wykluczenia emerytalnego $w$ wąskim ujęciu obejmujaca analizę zmian liczby uczestników dobrowolnych programów emerytalnych, wskaźników penetracji poszczególnych programów emerytalnych, oraz odsetka osób aktywnych ekonomicznie, nie korzystajacych z produktów emerytalnych.
\end{abstract}

Słowa kluczowe: wykluczenie finansowe, wykluczenie emerytalne, dobrowolne programy emerytalne.

JEL Codes: J-26, G-20, D-14.

\section{Wprowadzenie}

Zagadnienie wykluczenia finansowego poruszane jest w ostatnich latach dość często w literaturze przedmiotu. Temat jest o tyle ważny, że wykluczenie finansowe niesie ze sobą poważne skutki zarówno dla gospodarki, sektora finansowego, jak również samych konsumentów usług finansowych. Z tego względu Rada Unii Europejskiej i Parlament Europejski Europejskim ogłosiły rok 2010 Rokiem Walki z Ubóstwem i Wykluczeniem Społecznym. Za cel tego działania przyjęto zwiększenie świadomości opinii publicznej na temat ubóstwa i wykluczenia społecznego oraz wzrost zaangażowania politycznego Unii Europejskiej i krajów członkowskich w walkę z tymi zjawiskami ${ }^{1}$. Nie bez znaczenia dla wzrostu popularności tej problematyki były skutki

${ }^{1}$ B. Szopa, A. Szopa, Wykluczenie finansowe a wykluczenie społeczne, Zeszyty Naukowe PTE, nr 11, Kraków 2011, s. 13-27. 
ostatniego światowego kryzysu finansowego oraz pogarszające się ekonomiczne i społeczne warunki życia. W sytuacji tej szczególnego znaczenia nabiera kwestia ograniczania liczby osób i grup społecznych narażonych na wykluczenie finansowe. Jednym z obszarów wykluczenia finansowego jest pomijany w literaturze przedmiotu obszar związany z produktami emerytalnymi. Ograniczenie dostępu, czy trudności w korzystaniu z produktów mających na celu zabezpieczenie odpowiedniego dochodu jednostki w wieku emerytalnym stanowi poważny problem. Dla jego rozwiązania istotne jest, aby zjawisko to zdefiniować, poddać kwantyfikacji i monitorować - co dać może przyczynek do zmiany obecnej sytuacji. Stąd celem artykułu jest określenie istoty i miary wykluczenia emerytalnego oraz próba kwantyfikacji tego zjawiska w Polsce w latach 2006-2017. Zaprezentowana zostanie autorska definicja instytucjonalnego wykluczenia emerytalnego w szerokim i wąskim ujęciu, a także podjęta próba pomiaru instytucjonalnego wykluczenia emerytalnego w wąskim ujęciu.

\section{Wykluczenie finansowe - definicja, przyczyny, obszary}

W literaturze przedmiotu nie sformułowano jednoznacznej definicji zjawiska wykluczenia finansowego, które związane jest z wykluczeniem społecznym² ${ }^{2}$. Wskazuje się na możliwość wielokierunkowej zależności pomiędzy wykluczeniem finansowym i społecznym. W krajach Europy Zachodniej wykluczenie finansowe traktuje się jako przyczynę wykluczenia społecznego. W krajach rozwijających się jest to zależność odwrotna - wykluczenie społeczne jest przyczyną wykluczenia finansowego. Wykluczenie społeczne utożsamiane jest $\mathrm{z}$ doświadczaniem trudności w odniesieniu do swobodnego udziału w życiu społecznym i gospodarczym.

Tabela 1. Wykluczenie finansowe - przegląd definicji

\begin{tabular}{|l|l|}
\hline \multicolumn{1}{|c|}{ Autor } & \multicolumn{1}{|c|}{ Definicja wykluczenia finansowego } \\
\hline A. Leyshon i N. Thrift & $\begin{array}{l}\text { proces, w efekcie którego określone grupy społeczne mają } \\
\text { ograniczony dostęp do systemu finansowego }\end{array}$ \\
\hline Komisja Europejska & $\begin{array}{l}\text { proces, w którym ludzie napotykają problemy w dostępie i/lub w } \\
\text { korzystaniu z usług oraz produktów finansowych oferowanych } \\
\text { przez wiodące podmioty, które odpowiadałyby ich potrzebom i } \\
\text { umożliwiałyby im prowadzenie normalnego życia w społeczeństwie, } \\
\text { do którego należą }\end{array}$ \\
\hline $\begin{array}{l}\text { L. Anderloni i E.M. Carluccio } \\
\text { trudności, jakich doświadczają osoby o niskich dochodach i } \\
\text { znajdujące się w niekorzystnej sytuacji społecznej w korzystaniu } \mathbf{z} \\
\text { usług finansowych, które są im potrzebne }\end{array}$ \\
\hline $\begin{array}{l}\text { NBP, ZBP, Koalicja na Rzecz } \\
\text { Obrotu Bezgotówkowego } \\
\text { Mikropłatności }\end{array}$ & $\begin{array}{l}\text { niezdolność jednostek, gospodarstw domowych lub grup społecznych } \\
\text { do korzystania z niezbędnych usług finansowych w odpowiedniej } \\
\text { postaci }\end{array}$ \\
\hline
\end{tabular}

Źródło: opracowanie własne na podstawie: A. Leyshon, N. Thrift, op. cit., s. 314; European Commission, Financial Services Provision and Prevention of Financial Exclusion, Brussels, May 2008, s. 9-10, www.fininc.eu. dostęp z dnia 30.04.2019; L. Anderloni, E.M. Carluccio, Access to bank accounts and payment services. New Frontiers in Banking Services, Springer, Berlin 2007, s. 7; Strategia rozwoju obrotu bezgotówkowego w Polsce na lata 2009-2013, NBP, ZBP, Koalicja na Rzecz Obrotu Bezgotówkowego i Mikropłatności, Warszawa 2009, s. 54, http://www.nbp.pl/SystemPlatniczy/Obrot_bezgotowkowy/rob_projekt.pdf, dostęp z dnia 30.04.2019.

${ }^{2}$ E. Kempson, Policy Level Response to Financial Exclusion in Developer Countries: Lessons for Developing Countries, Paper for Access to Finance: Building Inclusive Financial Systems, World Bank, Washington 2006, s. 5 . 
Trudności te obejmują również sferę finansową. W przypadku wykluczenia finansowego podkreśla się jego ekonomiczny wymiar i związek z wykluczeniem społecznym $^{3}$. Wybrane definicje wykluczenia finansowego zaprezentowano w tabeli 1.

Funkcjonujące w literaturze przedmiotu definicje wykluczenia finansowego są w wielu aspektach zbieżne. Ich autorzy koncentrują się przede wszystkim na braku swobody korzystania z usług finansowych - oznaczającym trudności czy problemy w korzystaniu z tych usług, ograniczony dostęp, bądź niezdolność do korzystania z usług finansowych. Przyczyny występowania badanego zjawiska usystematyzowali E. Kempson i C. Whyley. Wyróżnili następujące rodzaje wykluczenia finansowego ${ }^{4}$ :

- ze względu na redukcję ryzyka podejmowanego przez instytucję finansową,

- ze względu na niedostępność geograficzną oraz niepewność danych identyfikacyjnych klienta,

- $\quad$ spowodowane niedopasowaniem usług oferowanych przez bank do potrzeb klientów,

- ze względu na cenę oferowanych usług nieadekwatną do poziomu dochodów klienta,

- $\quad$ spowodowane brakiem zainteresowania instytucji finansowej daną grupą społeczną,

- $\quad$ samowykluczenie rozumiane jako indywidualna decyzja jednostki o rezygnacji z usług dostarczanych przez instytucję finansową (jednostka ocenia, że nie może sobie pozwolić na korzystanie z takich usług, lub - że instytucja finansowa odmówi dostępu do danej usługi).

Wśród zaprezentowanych przyczyn wykluczenia finansowego wskazać można czynniki popytowe oraz podażowe ${ }^{5}$. Do czynników popytowych zaliczyć można: wykluczenie ze względu na warunki oraz samowykluczenie, zaś do czynników podażowych wykluczenie ze względu na: dostęp, cenę, politykę marketingową instytucji finansowej. W literaturze przedmiotu wskazuje się również na przyczyny społeczne analizowanego zjawiska. Wymienić tu można: zmiany strukturalne na rynku pracy, zmiany demograficzne, nierówność dochodów, politykę fiskalną, czy liberalizację rynków finansowych ${ }^{6}$.

Warto zauważyć, że wykluczenie finansowe dotyczy korzystania z usług finansowych o różnorodnym charakterze. Stąd Bank Światowy wyróżnia kilka obszarów wykluczenia finansowego, odpowiadających usługom finansowym z zakresu: bankowości transakcyjnej, oszczędności, kredytów, ubezpieczeń ${ }^{7}$. W polskiej literaturze przedmiotu funkcjonuje również bardziej rozbudowana klasyfikacja obszarów wykluczenia finansowego, uwzględniająca charakter instrumentów finansowych, do

\footnotetext{
${ }^{3}$ A. Leyshon, N. Thrift, Geographies of financial exclusion, financial abandonment in Britain and the United States, Transactions of the Institute of British Geographers, New Series, Vol. 20, No. 3, 1995, s. 314.

${ }^{4}$ E. Kempson, C. Whyley, Understanding and combating financial exclusion, Insurance Trends, Vol. 21/1999, s. 18-22 oraz E. Kempson, C. Whyley, Kept in or opted out? Understanding and combating financial exclusion, Policy Press, Bristol 1999.

${ }^{5}$ M. Penczar (red.), Rola edukacji finansowej w ograniczaniu wykluczenia finansowego, Instytut Badań nad Gospodarką Rynkową, Gdańsk 2014, s. 28.

${ }^{6}$ A. Borcuch, Instytucja wykluczenia finansowego $w$ wymiarze płatności bezgotówkowych, Studia i Materiały. Miscellanea Oeconomicae 16 (1), Wydział Zarządzania i Administracji Uniwersytetu Jana Kochanowskiego w Kielcach, Kielce 2012.

${ }^{7}$ European Commission, op. cit., s. 9-10, www.fininc.eu. dostęp z dnia 30.04.2019.
} 
których dostęp poszczególnych jednostek lub grup społecznych może być ograniczony. Wymienia się wykluczenie ${ }^{8}$ :

- płatnicze,

- inwestycyjne,

- ubezpieczeniowe,

- emerytalne,

- kredytowe,

- oszczędnościowe.

Przywołany podział wykluczenia finansowego - wyodrębniający m.in. kategorię wykluczenia emerytalnego - stał się inspiracją do powstania niniejszego artykułu. Ze względu na brak uszczegółowionej definicji poszczególnych rodzajów wykluczenia finansowego w zaprezentowanej klasyfikacji przedstawiona zostanie autorska koncepcja wykluczenia emerytalnego.

\section{Wykluczenie emerytalne - definicja i pomiar}

Świadomość wielowymiarowego charakteru zjawiska wykluczenia finansowego wynikającego $\mathrm{z}$ różnorodności usług finansowych daje możliwość równoległego prowadzenia badań nad ograniczeniami $\mathrm{w}$ korzystaniu $\mathrm{z}$ poszczególnych usług finansowych. Jest to szczególnie istotne zważywszy na fakt, iż w opracowaniach naukowych poświęconych wykluczeniu finansowemu wyraźnie dominuje tematyka ograniczoności dostępu do usług bankowych. W kontekście zainteresowań badawczych autorki dotyczących rozwoju dobrowolnych form zabezpieczenia emerytalnego funkcjonujących w ramach III filaru polskiego systemu emerytalnego - szczególnie interesujące wydaje się zdefiniowanie oraz pomiar wykluczenia emerytalnego.

Funkcjonujący w polskiej literaturze przedmiotu podział wykluczenia finansowego zaprezentowany we wcześniejszej części artykułu obejmuje obok wykluczenia płatniczego, kredytowego i ubezpieczeniowego m.in. takie kategorie wykluczenia jak: emerytalne, oszczędnościowe, czy inwestycyjne. W opinii autorki trzy ostatnie $\mathrm{z}$ wymienionych kategorii wykluczenia finansowego nie są rozłączne i wymagają większej precyzji w ich definiowaniu. Charakter dużej części usług finansowych (lokat bankowych, planów systematycznego oszczędzania, dobrowolnych form zabezpieczenia emerytalnego, odwróconej hipoteki) nosi bowiem pierwiastek zarówno formy oszczędności, czy inwestycji oraz może zabezpieczać cele emerytalne. Wykluczenie emerytalne ma więc wspólną płaszczyznę zarówno z wykluczeniem oszczędnościowym, jak i inwestycyjnym - w zakresie takim, w jakim tworzone oszczędności, czy realizowane inwestycje mają służyć zabezpieczeniu emerytalnemu.

Ze względu na złożoną architekturę systemów emerytalnych oraz niską homogeniczność produktów finansowych umożliwiających realizację celów emerytalnych, zdefiniowanie oraz pomiar wykluczenia emerytalnego stanowi duże wyzwanie.

\footnotetext{
${ }^{8}$ T. Koźliński, Wykluczenie płatnicze w Polsce $i$ innych krajach Unii Europejskiej, NBP, Warszawa 2010, https://www.nbp.pl/systemplatniczy/wykluczeniefinansowe/download/wykluczenie_platnicze_w_polsce_i_inn ych_krajach_ue.pdf. dostęp z dnia 30.04.2019.
} 
$\mathrm{Z}$ pewnością nie nastręcza problemu zdefiniowanie wykluczenia emerytalnego w zawężonym ujęciu instytucjonalnym. Jest to wykluczenie emerytalne odnoszące się wyłącznie do problemu korzystania czy dostępności jednostek do produktów emerytalnych funkcjonujących $\mathrm{w}$ ramach poszczególnych filarów danego systemu emerytalnego. Podstawowym kryterium różnicującym produkty emerytalne w ramach filarów jest obligatoryjność partycypacji w nich, co daje naturalną możliwość ich klasyfikacji. Przyjmując to kryterium podziału produktów emerytalnych instytucjonalne wykluczenie emerytalne w szerokim ujęciu dotyczy sytuacji, w której jednostka ma ograniczony dostęp do wszystkich funkcjonujących w ramach systemu emerytalnego form zabezpieczenia - zarówno obligatoryjnych, jak i dobrowolnych (całkowite wykluczenie $\mathrm{z}$ systemu emerytalnego). Instytucjonalne wykluczenie emerytalne w wąskim ujęciu dotyczy zaś sytuacji, w której jednostka ma ograniczony dostęp jedynie do dobrowolnych, dodatkowych form zabezpieczenia emerytalnego (funkcjonujących w Polsce w ramach III filaru systemu emerytalnego).

Zdefiniowane instytucjonalne wykluczenie emerytalne (w wąskim i szerokim ujęciu) stanowi oczywiście specyficzną czesśc zjawiska wykluczenia emerytalnego. Pamiętać należy bowiem, że poza instytucjonalnymi produktami emerytalnymi usankcjonowanymi prawnie $\mathrm{w}$ ramach systemu emerytalnego oszczędzanie na cele emerytalne może przebiegać $\mathrm{z}$ wykorzystaniem różnorodnych produktów/usług finansowych. Wykluczenie emerytalne w najszerszym kontekście obejmie więc osoby, które doświadczają trudności lub niezdolne są do zabezpieczenia dochodu emerytalnego w jakikolwiek sposób - nie są uczestnikami systemu emerytalnego oraz nie oszczędzają na cele emerytalne wykorzystując inne produkty/usługi finansowe.

Dobór miar instytucjonalnego wykluczenia emerytalnego - w obu podejściach - jest konsekwencją przyjętych definicji. Pomiaru instytucjonalnego wykluczenia emerytalnego w szerokim ujęciu dokonać można w oparciu o odsetek osób nie objętych zabezpieczeniem emerytalnym $\mathrm{w}$ jakiejkolwiek $\mathrm{z}$ form istniejących $\mathrm{w}$ ramach systemu emerytalnego. Miarą instytucjonalnego wykluczenia emerytalnego w wąskim ujęciu jest zaś odsetek osób nie korzystających z poszczególnych, dobrowolnych form zabezpieczenia emerytalnego. Warto podkreślić, że miara ta jest odwrotnością wskaźnika penetracji dobrowolnych form zabezpieczenia emerytalnego, odzwierciedlającego skale uczestnictwa w dobrowolnych programach emerytalnych. Wskaźnik szacowany jest jako iloraz liczby uczestników analizowanych form zabezpieczenia emerytalnego oraz liczby osób aktywnych zawodowo, gdzie ludność aktywna zawodowo definiowana jest jako wszyscy pracujący zawodowo (pracodawcy, pracownicy najemni, pracujący na własny rachunek, nieodpłatnie pomagający członkowie rodzin) oraz zarejestrowani bezrobotni ${ }^{9}$. Interpretacyjnie pozwala na określenie odsetka osób pracujących oraz poszukujących pracy, które oszczędzają na emeryturę w PPE, IKE, IKZE, czy w PPK.

Warto podkreślić, że pomiar wykluczenia emerytalnego w zaprezentowanej konwencji nie jest zadaniem prostym, głównie ze względu na ograniczenia w dostępności danych. Również zróżnicowanie architektury systemów emerytalnych

${ }^{9}$ Metainformacje. Słownik pojęć, GUS, Warszawa 2011, https://stat.gov.pl/metainformacje/slownikpojec/pojecia-stosowane-w-statystyce-publicznej/1126,pojecie.html, dostęp z dnia 5.05.2019. 
w poszczególnych krajach jest czynnikiem utrudniającym międzynarodowe porównania skali wykluczenia emerytalnego.

Biorąc pod uwagę zakres tematyczny niniejszego opracowania - w dalszej części pracy analizowane będzie instytucjonalne wykluczenie emerytalne w ujęciu wąskim.

\section{Pomiar instytucjonalnego wykluczenia emerytalnego w wąskim ujęciu w Polsce w latach 2006-2017}

Zgodnie $\mathrm{z}$ przyjętą $\mathrm{w}$ artykule definicją instytucjonalne wykluczenie emerytalne w wąskim ujęciu dotyczy sytuacji, w której jednostka ma ograniczony dostęp do dobrowolnych form zabezpieczenia emerytalnego funkcjonujących $\mathrm{w}$ danym systemie emerytalnym. W polskim systemie emerytalnym funkcjonuja obecnie cztery rodzaje dobrowolnych programów emerytalnych: Pracownicze Programy Emerytalne (PPE), Indywidualne Konta Emerytalne (IKE), Indywidualne Konta Zabezpieczenia Emerytalnego (IKZE) i Pracownicze Programy Kapitałowe (PPK). Czwarta dobrowolna forma oszczędzania emerytalnego - PPK - rozpoczęła funkcjonowanie w połowie 2019 roku i będzie wprowadzana etapami - począwszy od 1 lipca 2019 roku do PPK przystapili najwięksi pracodawcy, zatrudniający powyżej 250 pracowników, w ostatniej kolejności - w 2021 roku - małe firmy oraz jednostki sektora finansów publicznych ${ }^{10}$.

W celu oceny skali instytucjonalnego wykluczenia emerytalnego w wąskim ujęciu w Polsce - mierzonego odsetkiem osób aktywnych ekonomicznie i niekorzystających z dostępnych, dobrowolnych programów emerytalnych - przeprowadzona zostanie analiza rynku PPE, IKE, IKZE (PPK zostaną pominięte w analizie ze względu na zbyt krótki okres ich funkcjonowania, implikujący brak danych $\mathrm{z}$ badanego zakresu) z uwzględnieniem zmian dwóch podstawowych wielkości charakteryzujących ten rynek:

- liczby uczestników poszczególnych programów emerytalnych,

- $\quad$ wskaźników penetracji dobrowolnych programów emerytalnych.

Wyniki analizy zmian wskazanych wielkości pozwolą na oszacowanie przyjętej miary instytucjonalnego wykluczenia emerytalnego w wąskim ujęciu.

Analiza liczby uczestników dobrowolnych programów emerytalnych w Polsce napotyka na podstawowy problem agregacji osób oszczędzających na cele emerytalne. Ze względu na ustawową możliwość jednoczesnego uczestnictwa we wszystkich formach funkcjonujących w III filarze oraz brak statystyk uwzględniających fakt uczestnictwa w kilku różnorodnych programach liczbę uczestników III filaru oszacować można jedynie z dużym przybliżeniem. Rzeczywista zagregowana liczba uczestników dobrowolnych programów emerytalnych $w$ Polsce jest bowiem niższa od sumy uczestników IKE, PPE, IKZE. Jej urealnienie poprzez wyeliminowanie podwójnego lub nawet potrójnego uczestnictwa w III filarze nie jest obecnie możliwe, tak jak i oszacowanie skali zjawiska polegającego na korzystaniu $z$ więcej niż jednego programu emerytalnego. Zmiany liczby uczestników dobrowolnych programów emerytalnych w Polsce w latach 2006-2017 zaprezentowano w tabeli 2.

Dobrowolną formą oszczędzania na cele emerytalne skupiającą największą liczbę uczestników są w Polsce IKE, następnie IKZE oraz PPE. Na koniec 2017 roku

${ }^{10}$ Art. 134 Ustawy z dnia 4 października 2018 roku o pracowniczych planach kapitałowych (Dz. U. 2018 poz. 2215). 
Indywidualne Konta Emerytalne posiadało 951,6 tys. osób (dopiero w 2017 roku liczba IKE przekroczyła poziom 915,5 tys. kont - osiagnięty przed kryzysem finansowym w 2007 roku). Warto podkreślić, że spadkowi liczby IKE w okresie kryzysu finansowego nie towarzyszył spadek liczby uczestników PPE. Z obserwacji tych można wysnuć wniosek, że łatwiej „wyjść” $\mathrm{z}$ inwestycji emerytalnej o charakterze indywidualnym, niż grupowym. Z perspektywy wprowadzanych do systemu emerytalnego PPK wydaje się to korzystnym mechanizmem, zwiększającym stabilność długoterminowych oszczędności emerytalnych.

Tabela 2. Liczba uczestników dobrowolnych programów emerytalnych w Polsce w latach 2006-2017 (w tys.)

\begin{tabular}{|c|c|c|c|}
\hline Rok & Liczba uczestników PPE & Liczba IKE & Liczba IKZE \\
\hline 2006 & 281,5 & 840,3 & 0,0 \\
\hline 2007 & 312,1 & 915,5 & 0,0 \\
\hline 2008 & 325,0 & 853,8 & 0,0 \\
\hline 2009 & 333,5 & 809,2 & 0,0 \\
\hline 2010 & 342,5 & 792,5 & 0,0 \\
\hline 2011 & 344,6 & 814,4 & 0,0 \\
\hline 2012 & 358,1 & 813,3 & 32,8 \\
\hline 2013 & 375,0 & 817,7 & 496,4 \\
\hline 2014 & 381,0 & 824,5 & 528,1 \\
\hline 2015 & 392,6 & 855,2 & 597,3 \\
\hline 2016 & 395,6 & 867,8 & 643,1 \\
\hline 2017 & 395,8 & 951,6 & 691,0 \\
\hline
\end{tabular}

Źródło: opracowanie własne na podstawie raportów rocznych KNF - Biuletyny roczne. Rynek PPE, raporty za lata 2006-2017, KNF, https:/www.knf.gov.pl/opracowania/rynek_emerytalny/dane_o_rynku/rynek_ppe_ike/Dane_roczne/roczne_pp e.html [dostę 5.04.2019]; Informacje liczbowe o rynku IKE, raporty za lata $2006-2017, \overline{K N F}$, Warszawa, http:/www.knf.gov.pl/opracowania/rynek emerytalny/dane_o_rynku/rynek_ppe ike/Dane_IKE/dane_ike.htm

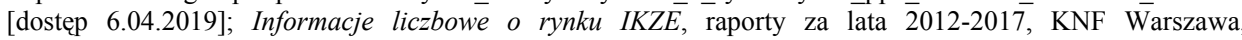
https://www.knf.gov.pl/opracowania/rynek_emerytalny/dane_o_rynku/rynek_ppe_ike/Dane_IKZE/dane_ikze. html [dostęp 8.04.2019].

W ocenie podmiotowej struktury rynku dobrowolnych form emerytalnych na uwagę zasługuje również fakt, iż druga pod względem liczebności uczestników forma oszczędzania emerytalnego - IKZE - funkcjonuje zaledwie kilka lat. Sukcesu IKZE upatrywać można prawdopodobnie w zastosowanym mechanizmie opodatkowania, pozwalającym na uzyskanie korzyści podatkowych w momencie płacenia składki na IKZE - ulga podatkowa w postaci możliwości odliczenia od podstawy opodatkowania podatkiem dochodowym od osób fizycznych kwot wpłat na to konto, dokonanych przez oszczędzającego $\mathrm{w}$ danym roku podatkowym, do wysokości określonej $\mathrm{w}$ przepisach o IKZE ${ }^{11}$

Wśród funkcjonujących, dobrowolnych form oszczędzania na emeryturę Pracownicze Programy Emerytalne skupiają najmniejszą liczbę uczestników, mimo iż są najstarszą dobrowolną formą oszczędzania w Polsce. W analizowanym okresie liczba uczestników PPE stale rosła z 281,5 tys. do 395,8 tys. osób. Wzrost ten następował

${ }^{11}$ Art. 26 ust. 1 pkt 2b Ustawy z dnia 26 lipca 1991 roku o podatku dochodowym od osób fizycznych (Dz.U.2018.0.1509). 
pomimo spadku liczby tworzonych PPE w latach $2012-2017^{12}$. W dalszym rozwoju PPE $\mathrm{w}$ Polsce $\mathrm{z}$ pewnością interesujące będą kolejne etapy wprowadzania PPK, które diametralnie zmieni obraz III filara systemu emerytalnego w Polsce. Równoległe funkcjonowanie bliźniaczych PPE i PPK stanowić będzie duże wyzwanie dla ustawodawcy, aby zapewnić obu programom takie warunki funkcjonowania, aby nie stanowiły one konkurencji względem siebie, lecz uzupełniały się wzajemnie i wychodziły naprzeciw innym oczekiwaniom i potrzebom ${ }^{13}$ (KNF, 2018).

Dane dotyczące liczby uczestników analizowanych programów w Polsce pozwalają na oszacowanie wartości wskaźników penetracji stanowiących stosunek liczby uczestników badanych form emerytalnych do liczby osób aktywnych ekonomicznie (tabela 3).

Tabela 3. Wskaźniki penetracji dobrowolnych form zabezpieczenia emerytalnego w Polsce w latach 2006-2017 (w \%)

\begin{tabular}{|c|r|r|r|r|}
\hline Rok & \multicolumn{1}{|c|}{$\begin{array}{c}\text { Zagregowany wskaźnik } \\
\text { penetracji wszystkich form } \\
\text { zabezpieczenia emerytalnego* }\end{array}$} & $\begin{array}{c}\text { Wskaźnik } \\
\text { penetracji PPE }\end{array}$ & $\begin{array}{c}\text { Wskaźnik } \\
\text { penetracji IKE }\end{array}$ & $\begin{array}{c}\text { Wskaźnik } \\
\text { penetracji IKZE }\end{array}$ \\
\hline 2006 & 6,7 & 1,7 & 5,0 & - \\
\hline 2007 & 7,3 & 1,8 & 5,4 & - \\
\hline 2008 & 6,9 & 1,9 & 5,0 & - \\
\hline 2009 & 6,6 & 1,9 & 4,6 & - \\
\hline 2010 & 6,6 & 2,0 & 4,6 & 0,2 \\
\hline 2011 & 6,7 & 2,0 & 4,7 & 2,8 \\
\hline 2012 & 7,0 & 2,1 & 4,7 & 3,0 \\
\hline 2013 & 9,7 & 2,2 & 4,7 & 3,4 \\
\hline 2014 & 10,0 & 2,2 & 4,8 & 3,9 \\
\hline 2015 & 10,6 & 2,2 & 5,0 & \\
\hline 2016 & 11,0 & 2,3 & 5,5 & \\
\hline 2017 & 11,9 & 2,3 & 3,7 \\
\hline
\end{tabular}

*do szacowania zagregowanego wskaźnika penetracji wszystkich form zabezpieczenia emerytalnego wykorzystano zagregowaną liczbę uczestników PPE, IKE i IKZE.

Źródło: opracowanie własne na podstawie raportów rocznych KNF - Biuletyny roczne. Rynek PPE, raporty za lata 2006-2017, KNF, Warszawa, https://www.knf.gov.pl/opracowania/rynek_emerytalny/dane_o_rynku/rynek_ppe_ike/Dane_roczne/roczne_pp

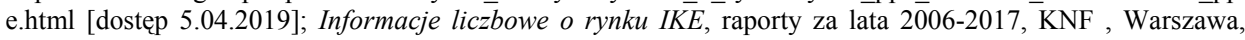
http://www.knf.gov.pl/opracowania/rynek emerytalny/dane o rynku/rynek ppe ike/Dane IKE/dane ike.html [dostęp 6.04.2019]; Informacje liczbowe o rynku IKZE, raporty za lata 2012-2017, KNF Warszawa, https://www.knf.gov.pl/opracowania/rynek emerytalny/dane o rynku/rynek ppe ike/Dane IKZE/dane ikze. html [dostęp 8.04.2019] oraz raportów rocznych GUS - Aktywność ekonomiczna ludności Polski, raporty za lata 2006-2017, GUS, Warszawa, https://stat.gov.pl. [dostęp 8.04.2019].

Wyniki analizy zmian wartości wskaźników penetracji dobrowolnych form zabezpieczenia emerytalnego pozwalają ocenić stopień ich rozwoju w Polsce jako bardzo niski. W latach 2006-2017 wartość zagregowanego wskaźnika penetracji

\footnotetext{
${ }^{12}$ Biuletyny roczne. Rynek PPE, raporty za lata 2006-2017, KNF, Warszawa, https://www.knf.gov.pl/opracowania/rynek_emerytalny/dane_o_rynku/rynek_ppe_ike/Dane_roczne/roczne_pp e.html [dostęp 5.04.2019].

${ }_{13}$ Pracownicze Programy Emerytalne w 2017 roku, KNF, Warszawa 2018, s. 37-38, https://www.knf.gov.pl/?articleId=62266\&p_id=18, dostęp z dnia 10.05.2019.
} 
dobrowolnych form zabezpieczenia emerytalnego wzrosła z poziomu $6,7 \%$ do $11,9 \%$. Oznacza to, że na koniec 2017 roku niespełna dwanaście procent aktywnych ekonomicznie Polaków oszczędzało na emeryturę w III filarze systemu emerytalnego. Należy podkreślić, iż rzeczywiste wartości zagregowanego wskaźnika penetracji wszystkich form zabezpieczenia emerytalnego są jeszcze niższe ze względu na możliwość dwu lub trzykrotnego uwzględnienia w analizowanej mierze osób korzystających równolegle $\mathrm{z}$ kilku dobrowolnych form zabezpieczenia emerytalnego. Warto wskazać, iż wyższymi wartościami wskaźników penetracji charakteryzowały się indywidualne programy emerytalne - IKE i IKZE, niższy zaś był stopień uczestnictwa osób aktywnych ekonomicznie w programach pracowniczych. Na koniec 2017 roku $\mathrm{w}$ formach indywidualnych oszczędzało łącznie 9,5\% uczestników rynku, w formie pracowniczej było to zaledwie $2,3 \%$.

Wyniki analizy stopnia partycypacji polskiego społeczeństwa w dobrowolnych formach zabezpieczenia emerytalnego pozwalają na określenie skali - zdefiniowanego w wąskim ujęciu - instytucjonalnego wykluczenia emerytalnego w Polsce. Zmiany odsetka osób aktywnych ekonomicznie i niekorzystających $\mathrm{z}$ dobrowolnych form zabezpieczenia emerytalnego zaprezentowano na wykresie 1 .

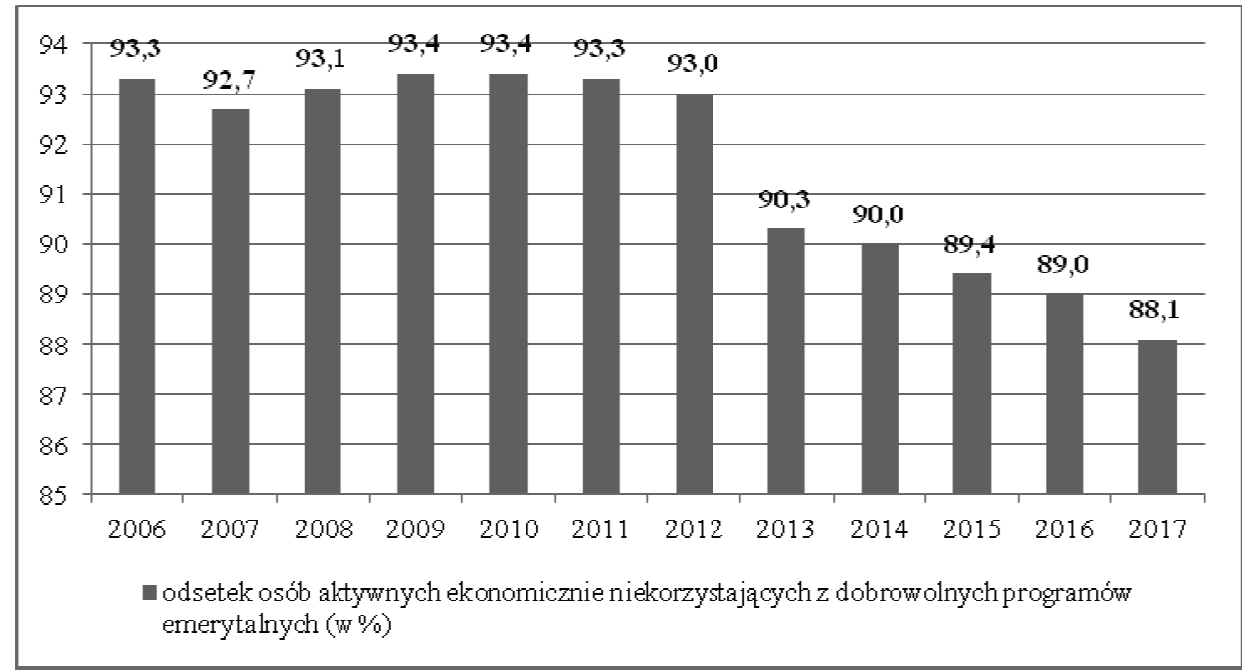

Wykres 1. Skala instytucjonalnego wykluczenia emerytalnego w wąskim ujęciu w Polsce w latach 2006-2017 Źródło: opracowanie własne na podstawie danych z Tabeli 3.

Instytucjonalne wykluczenie emerytalne $\mathrm{w}$ wąskim ujęciu obejmuje $\mathrm{w}$ Polsce znaczną część społeczeństwa. Na koniec 2017 roku ponad 88\% osób aktywnych ekonomicznie nie uczestniczyło $\mathrm{w}$ żadnej formie dobrowolnego oszczędzania na emeryturę. Świadczy to o bardzo niskiej popularności produktów oszczędnościowych tworzonych w ramach III filara polskiego systemu emerytalnego. Pozytywnie ocenić można jednak stały, spadkowy trend analizowanej miary - w latach 2010-2017 odsetek osób aktywnych ekonomicznie i niekorzystających z dobrowolnych programów emerytalnych spadł o ponad 5 punktów procentowych. 
Warto nadmienić, że w perspektywie realizujących się (rozpoczęcie działalności przez PKK od 1 lipca 2019 roku) oraz planowanych zmian (likwidacja OFE) polskiego systemu emerytalnego ukształtowany obecnie poziom wykluczenia emerytalnego zwianego $\mathrm{z}$ ograniczeniami $\mathrm{w}$ korzystaniu $\mathrm{z}$ dobrowolnych form oszczędzania na emeryturę ulegnie znacznym zmianom. Zastosowany w konstrukcji PPK mechanizm automatycznego zapisu, z możliwością rezygnacji może wspomóc proces stopniowego ograniczania instytucjonalnego wykluczenia emerytalnego w wąskim ujęciu - za sprawą powszechności tego rozwiązania wśród osób pracujących oraz poprzez zaangażowanie pracodawcy jako podmiotu inicjującego korzystanie przez pracownika z programów emerytalnych. Część uczestników rynku nie będzie już odkładała momentu oszczędzania na emeryturę na późniejsze okresy, część osób dotychczas niezdecydowanych na świadome oszczędzanie na emeryturę nie podejmie wysiłku rezygnacji z programu. Również planowana likwidacja OFE i przekazanie części zgromadzonych w nich aktywów na IKE spowoduje dalszy spadek instytucjonalnego wykluczenia emerytalnego w wąskim ujęciu oraz dalsze, istotne zmiany strukturalne na rynku dobrowolnych programów emerytalnych w Polsce.

\section{Podsumowanie}

Instytucjonalne wykluczenie emerytalne $\mathrm{w}$ wąskim ujęciu - odnoszące się do ograniczonego uczestnictwa $w$ dodatkowych formach oszczędzania na emeryturę stanowi w Polsce poważny problem. Mimo, iż dobrowolne formy oszczędzania na cele emerytalne są integralnym elementem polskiego systemu emerytalnego od kilkunastu lat - poziom i dynamika ich rozwoju wydają się być niewystarczające. Niskie wartości wskaźników partycypacji w PPE, IKE, IKZE potwierdzają to - dodatkowo na cele emerytalne oszczędza niewielka część polskiego społeczeństwa. Analizowane w opracowaniu wykluczenie emerytalne dotyka prawie $90 \%$ ludzi aktywnych ekonomicznie.

Ze względu na istotny zakres zmian wprowadzanych w obszarze dobrowolnych programów emerytalnych na moment obecny ciężko przewidzieć możliwy kierunek zmian poziomu analizowanego wykluczenia emerytalnego w Polsce. Optymistyczne wydają się zapowiedzi dotyczące potencjalnej liczby pracowników objętych PPK $11,5 \mathrm{mln}$ osób $^{14}$ (Sikora, 2019). Na weryfikację tych prognoz trzeba jednak poczekać. Niewiadomą pozostaje również finalny kształt podmiotowej struktury rynku dobrowolnych programów emerytalnych w przyszłości.

Ze względu na ograniczony zakres niniejszego opracowania problematyka determinant, skutków i przeciwdziałania wykluczeniu emerytalnemu we wszystkich definiowanych w opracowaniu aspektach tego zjawiska - nie została poruszona, będzie ona przedmiotem odrębnych badań.

\footnotetext{
${ }^{14}$ P. Sikora, Pracownicze Plany Kapitałowe (PPK) - co to takiego i kiedy wejdzie w życie, Gazeta Prawna.pl, artykuł z dnia 16.04.2019, https://www.gazetaprawna.pl/ppk/artykuly/1315274,ppk-pracownicze-planykapitalowe-kiedy-wejda-w-zycie-skladki-wyplata.html, dostęp z dnia 30.04.2019.
} 


\section{Literatura:}

Aktywność ekonomiczna ludności Polski, raporty za lata 2006-2017, GUS, Warszawa, https://stat.gov.pl.

Anderloni L., Carluccio E.M., 2007: Access to bank accounts and payment services. New Frontiers in Banking Services, Springer, Berlin, s. 7.

Biuletyny roczne. Rynek PPE, raporty za lata 2006-2017, KNF, Warszawa,

https://www.knf.gov.pl/opracowania/rynek_emerytalny/dane_o_rynku/rynek_ppe_ike/Dane_roczn e/roczne_ppe.html.

Borcuch A., Instytucja wykluczenia finansowego $w$ wymiarze płatności bezgotówkowych, Studia i Materiały. Miscellanea Oeconomicae., Rok 16, Nr 1, Wydział Zarządzania i Administracji Uniwersytetu Jana Kochanowskiego w Kielcach, Kielce 2012.

European Commission, Financial Services Provision and Prevention of Financial Exclusion, Brussels 2008, s. 9-10, www.fininc.eu.

Informacje liczbowe o rynku IKE, raporty za lata 2006-2017, KNF, Warszawa,

http://www.knf.gov.pl/opracowania/rynek_emerytalny/dane_o_rynku/rynek_ppe_ike/Dane_IKE/d ane ike.html.

Informacje liczbowe o rynku IKZE, raporty za lata 2012-2017, KNF Warszawa, https://www.knf.gov.pl/opracowania/rynek_emerytalny/dane_o_rynku/rynek_ppe_ike/Dane_IKZE /dane ikze.html.

Kempson E., Policy Level Response to Financial Exclusion in Developer Countries: Lessons for Developing Countries, Paper for Access to Finance: Building Inclusive Financial Systems, World Bank, Washington 2006.

Kempson, E., Whyley C., Understanding and combating financial exclusion, Insurance Trends, Vol. 21/1999.

Kempson, E., Whyley, C., Kept in or opted out? Understanding and combating financial exclusion, Policy Press, Bristol 1999.

Koźliński T., Wykluczenie płatnicze w Polsce i innych krajach Unii Europejskiej, NBP, Warszawa 2010, https://www.nbp.pl/systemplatniczy/wykluczeniefinansowe/download/wykluczenie_platnicze_w_ polsce_i_innych_krajach_ue.pdf.

Leyshon A., Thrift N., Geographies of financial exclusion, financial abandonment in Britain and the United States, Transactions of the Institute of British Geographers, New Series, Vol. 20, No. 3, Bristol 1995.

Metainformacje. Stownik pojęć, GUS, Warszawa 2011, https://stat.gov.pl/metainformacje/slownikpojec/pojecia-stosowane-w-statystyce-publicznej/1126,pojecie.html.

Penczar M. (red.), Rola edukacji finansowej w ograniczaniu wykluczenia finansowego, Instytut Badań nad Gospodarką Rynkową, Gdańsk 2014.

Pracownicze Programy Emerytalne w 2017 roku, KNF, Warszawa 2018, s. 37-38, https://www.knf.gov.pl/?articleId=62266\&p_id=18.

Sikora P., Pracownicze Plany Kapitałowe (PPK) - co to takiego i kiedy wejdzie w życie, Gazeta Prawna.pl, artykuł z dnia 16.04.2019, https://www.gazetaprawna.pl/ppk/artykuly/1315274,ppkpracownicze-plany-kapitalowe-kiedy-wejda-w-zycie-skladki-wyplata.html.

Strategia rozwoju obrotu bezgotówkowego w Polsce na lata 2009-2013, NBP, ZBP, Koalicja na Rzecz Obrotu Bezgotówkowego i Mikropłatności, Warszawa 2009, http://www.nbp.pl/SystemPlatniczy/Obrot_bezgotowkowy/rob_projekt.pdf.

Szopa B., Szopa A., Wykluczenie finansowe a wykluczenie społeczne, Zeszyty Naukowe PTE, nr 11, Kraków 2011.

Ustawa z dnia 4 października 2018 roku o pracowniczych planach kapitałowych (Dz. U. 2018 poz. 2215).

Ustawa z dnia 26 lipca 1991 roku o podatku dochodowym od osób fizycznych (Dz.U.2018.0.1509). 


\begin{abstract}
The issue of financial exclusion is an important area of research in modern finance science, mainly due to the serious effects that this phenomenon implies in both the macro (for the economy and the financial sector) and micro scale (for consumers of financial services). Observing changes in demography (increasing life expectancy, aging of societies) and a drop in forecasted replacement rates in basic pension systems, the category of pension exclusion, which involves limited access of individuals to pension products, is of particular importance. The purpose of this paper is to determine the nature and measure of pension exclusion and attempt to quantify this phenomenon in Poland in the years 2006-2017. The originality of the study is the author's definition of institutional pension exclusion in both a broad and narrow perspective, as well as the attempt to measure institutional retirement exclusion in specific avenues, including: the analysis of changes in the number of voluntary pension scheme participants, penetration rates for individual pension programs and the percentage of economically active people not using pension products.
\end{abstract}

Keywords: financial exclusion, pension exclusion, voluntary pension plans.

JEL Codes: J-26, G-20, D-14.

Informacje o autorze:

Kamila Stańczak-Strumilło

Uniwersytet Gdański

ul. Armii Krajowej 101, 81-824 Sopot

e-mail: kamila.stanczak-strumillo@ug.edu.pl

ORCID: 0000-0001-8623-2387 